\title{
Music Entrepreneurship and Family Businesses: The Case of Avsenik Brothers Ensemble
}

\author{
MOJCA RAMŠAK \\ Department of Ethnology and Cultural Anthropology, \\ Faculty of Arts, University of Ljubljana
}

\begin{abstract}
The Avsenik Brothers Ensemble is by far the most successful Slovene music group performing popular-national music, having sold 36 million albums worldwide and having been featured in more than 10,000 live shows. Year 2013 marked the $60^{\text {th }}$ anniversary of successful music-making for the brothers Slavko Avsenik and Vilko Ovsenik. Today the family music tradition is actively pursued by Slavko's son Gregor, and grandson Sašo, who continue the artistry of the Avseniks and oversee the family business built around it. The article provides a historical qualitative description of the Avseniks' career, their business model, the milestones of their success, music expansion and building of the identity of popular-national music in Slovenia.
\end{abstract}

Key words: popular-national music, brothers Avsenik, Slovenia, music industry, business anthropology, leadership, music entrepreneurship

\section{OVERTURE}

In the fast-paced music industry, staying popular and maintaining a large, international fan base for 60 years is almost unheard of. The list of those achieving such heights is short. Yet, this accomplishment has been achieved by one of the most recognized Slovene groups of all time, The Avsenik Broters Ensemble. Famous for being representatives of the typical Slovene sound and its trade mark (Cvetko 2007: 53) popular-national music, ${ }^{1}$ also known

\footnotetext{
${ }^{1}$ Popular-national music is an overlooked phenomenon of contemporary culture, hence the terminology is not standardized. In the Slovene language we inconsistently write the adjective narodno-zabaven with a hyphen, separately (narodno zabaven) or together (narodnozabaven). Even in professional texts and translations into English we use different terms, such as: pop-folk music (Ferbežar 1995; Eterović 2008; Kovačič 2014), national-folk music (Juvančič 2004), polka music (Knific 2005b), national pop music (Juvančič 2005), popular-national music (Cvetko 2007), popular folk music (Jercog 2008; www.Avsenik.com), national-entertainment music, national folk music (Torkar 2008), folk national-entertaining music (Strašnik 2010). For this article I consulted more than 20 translators to help me find the "right"
} 
as Oberkrainer (music) in the German-speaking parts of Europe or more specifically as Avsenik music, their instrumental and vocal upbeat polkas, marches, nostalgic waltzes, and even tangos have sold 36 million albums worldwide and been featured in more than 10,000 live shows. Year 2013 marked the $60^{\text {th }}$ anniversary of successful music-making for the brothers Slavko Avsenik and Vilko Ovsenik.

From their beginnings in the small village of Begunje in the northwest alpine Upper Carniola region of Slovenia, their dedication to excellence and creativity has become a global phenomenon, spreading the music genre across Europe (particularly in German-speaking regions) and around the world. Today this family tradition is actively carried on by Slavko's son Gregor, and grandson Sašo who continue the artistry of the Avseniks and oversee the family business built around it. In the same small village of Begunje - still the headquarters of the Avseniks - they maintain an ensemble of seven musicians, run a restaurant, and operate a gallery, museum, music publishing house, music school and even a multipurpose community centre. Despite their success, and pride in it, the Avsenik family keeps humility at the forefront, avoiding publicity, staying true to their modest beginnings, and committing to persistent hard work, professionalism, and spirit of collaborative creativity (with some fortunate turns), that paved their road to success.

This article is based primarily on published books, journals, radio/film documentaries and interviews. Because of objective circumstances (the health of both brothers Avsenik/Ovsenik) I have made only one short interview with Slavko Avsenik and several semi-structured interviews with his wife Brigita (in years 2013 and 2014), who helped official ensemble managers run the family business. The selection and combination of the used sources show the musicians, their families and managers in different business settings; their thoughts, attitude towards the strategic planning of the ensemble, leadership practices, professionalism and the varying circumstances that affected the functioning of the Avseniks. Such a review of Avsenik business operations has not yet been made, so the article presents, among other things, some of their statements from television and other interviews, which represent significant material on this subject. I intervened in the material only so as to edit the spoken language adapting it to readers in a way which maintains the substance of the message of the speakers. The com-

translation of the term narodno-zabavna glasba, but even they have not been able to agree on the most appropriate term. As an ethnologist I could see the logic in their suggestions, led by their music preferences and taste. It was interesting - but nothing new - to see what they think about this genre. The terms they suggested were: oberkrainer music, pop-folk oberkrainer music, turbo (cow) folk, traditional music, ethnic popular music, folk tinged pop, "oompah" music, beef soup music, alpine folk music, cronecore, etc. So, after considering all the existent professional translations and new suggestions obtained in March 2015, I decided to use the term popular-national music as it was used in the exhibition Sounds of Slovenia: from folk musicians to the Avseniks (Cvetko 2007) in The Slovene Ethnographic Museum in Ljubljana. 
plete text in Slovene was authorized twice by the members of the Avsenik family. I thank them for their cooperation, clarifications and understanding, especially because they would rather choose to be introduced as musicians and not as entrepreneurs.

In addition to these sources, I also used other case studies from different business schools about successful musicians, music groups or business situations of the musicians, and texts from business anthropology where I observed parallels with the Avseniks (See Bahanan and Playfoot 2004; Chakravorti, Kraus and Spence 2012; Martilla 2012; Austin and O'Donnell 2007; Saintilan 2013a, 2013b, 2013c; Saintilan and Cannon 2013; O'Donnell 2011; Spang Goodrich and Rossiter 2010; Rossiter, Spang Goodrich and Shaw 2011).

\section{BACKGROUND AND ORIGINS - THE AVSENIK/OVSENIK BROTHERS AND THE IDENTITY OF POPULAR-NATIONAL MUSIC}

The musical style of the Avseniks has tended to be classified as popularnational music (narodno-zabavna glasba). This term actually refers to a number of related styles from the Alpine regions of Slovenia, Austria, Germany, Switzerland, Italian South Tirol and the Czech Republic. Arising from rural farming communities and their cultural traditions, it invokes local and regional "folk" styles present at fêtes, weddings, festivals and competitions. In German speaking areas, the Avseniks and their style have been termed Oberkrainer. ${ }^{2}$ The name derives from the German "das Land Krain", the historic-geographic name for "Kranjska", a region that comprises parts of present-day Slovenia (Upper Carniola, Lower Carniola and to a lesser degree Inner Carniola) and is the current German name for Upper Carniola - "Gorenjska".

The Avsenik's style of music is closely linked to the accordion, but also encompasses horns and stringed instruments like guitars, fiddles and zithers. Vocally, the music is melodious with simple harmonizations and occasional yodelling (a common tradition across Alpine Europe). ${ }^{3}$ Rhythmically, the

\footnotetext{
${ }^{2}$ The German names on the records and compact discs occur in many different versions: Oberkrainer Quartett, Oberkrainer Quintett, Oberkrainer Quintett Avsenik, Original Oberkrainer, Original Oberkrainer Quintett, Original Oberkrainer Quintett Avsenik, Slavko Avsenik und Original Oberkrainer, Slavko Avsenik und seine Original Oberkrainer. These names have different components and show the transformation of a group of musicians, both quantitatively as well as regarding the variety of ways of stressing the function of the family, the leading musician and the originality of their music.

${ }^{3}$ Yodelling is defined as singing without words, typical mainly of the German-speaking Alpine regions and, although to a lesser extent, of northern Italy and the French-speaking parts of Switzerland. Yodelling was not practiced in Slovene folk music, although it bears certain characteristics of the Alpine cultural area as well. On the rare occasions when it was used, it was perceived as strange and alien to the Slovene
} 
music owes its rhythm to the polka and waltz traditions, though the Avseniks have also incorporated rhythms from tango and pop music.

The mixing of popular and traditional music can be found around the world. This mixture of old and new, valuing the past for a musical future, can be found in traditions such as the American country, the French-American zydeco and Cajun, the Turkish Arabesque, the Indonesian Kroncong, the Japanese Enka or the European polka. All these genres reinvent rural identities through music and dance (Muršič 2000: 146). Stemming from classical folk music, after World War II, the number of bands active in the tradition - from amateur to professional - increased significantly. The Avseniks are not alone in this. In post-war "new" Europe, such music found a favourable cultural, political and historical climate for market expansion, helped significantly by the spread of new recording and communication technologies in the music industry.

Popular-national music captures themes from the countryside, evoking cultural memories in those from or connected to such rural areas. Brothers Avsenik, who were shaped in the early post-war years through countryside fêtes, popular-national music festivals, Alpine evenings, ${ }^{4}$ and so forth, became successful when this music spread to a wider circle of listeners through radio and television. Their music became an important source of Slovene national identity, particularly through media exposure and a growing popularity of nostalgic, invented traditions based on stylized rural Alpine culture. The media represent the Alpine style in popular-national music with images of vigorous, idealised rural Slovenes from the mountains, but also from the other wine regions and cities. The rural and rural-working populations, who traditionally enjoy this style of music, were the original market niche for the Avseniks.

"The Alpine culture of Slovenehood" (alpska kultura slovenstva) is not just a geographical dimension, but embraces other identifiable Alpine identities, in its scope e.g.: Triglav, the highest mountain in Slovenia and a mythical symbol, the wreaths of the snowy Alps, the Island of Bled, Prešeren's The Baptism on the Savica (Krst pri Savici, 1836), youth literary character, the mountain shepherd Kekec, the first Slovene silent film In the Kingdom of Zlatorog (V kraljestvu Zlatoroga, 1931) and The Triglav Steep Slopes (Triglavske strmine, 1932), churches on the hills, pilgrimage, mountaineering, Alpine climbing, skiing, Planica ski jumps, good will and night debauchery in the mountain huts, postcards and calendars with mountain motives, alpine flora

\footnotetext{
popular tradition. During the last decades, yodelling has become much more frequently used in Slovene popular music, but mainly to mock their northern neighbours. Due to the impact of the radio, television, records, tapes, and compact discs, yodelling has now become a part of the Slovene musical style. In Slovenia, yodelling attracted attention due to The Avsenik Brothers Ensemble (Marty 2007).

${ }^{4}$ The first Alpine evening (Alpski večer) took place in 1986.
} 
and fauna, waterfalls, red carnations on the windows, Carniolan sausage with sauerkraut, polenta and sour milk, cheese, alpine milk, Juliana water, Alpine and Kekec pate, mountain tea, Zlatorog beer and soap, red Upper Carniolan umbrellas and Upper Carniolan national costumes, the accordion, popular-national music, etc. (Šaver 2005).

Alpine motifs in the Avseniks' popular-national music refer to the cultural image of the mountainous terrain ${ }^{5}$ and to the Alpine culture of Slovenehood as dominant cultural imagery. The Alpine motifs are also represented by the other popular-national music groups and they became part of the media folklore.

Sentimental, indigenous motifs with a stark contrast between the native village (the countryside - Upper Carniola, especially in older texts) and the city, and between the native and foreign countries are common in the music of the Avseniks. The city and foreign countries signify disorder, they are referred to as negative, gray and cold, where a man feels lonely and helpless. The themes in the texts are a kind of nostalgia for a youth spent at the fireplace with the family and flirt with older listeners - as well as Slovene expatriates. The most common background is nature in all its idyll, again as an opposition to the city, as well as a reminder of the ecological and morally impeccable times (Ferbežar 1995: 335-336).

Popular-national music grew out of the pre-industrial era of folk musical traditions, changed through modern tastes to meet the desires of a wide segment of the population. At the end of the Second World War a large part of the rural population moved to industrial areas. This music reminded them of home and created idyllic images to which they connected. Radio programming of this music influenced people's tastes and began to form an important part of leisure-time music consumption. Over the years of war, fear, misery and rebuilding the country, listeners needed entertainment. During socialism, it redirected their thoughts and brought a forbidden taste of the foreign countries and western mentality to Slovenia. At the same time, after the war, songs featuring religious and folk themes were politically shunned. Popularnational music quickly adapted to this situation. Because of the radio show "Thursday Evening with Local Songs and Tunes" (Četrtkov večer domačih pesmi in napevov) people purchased radios en mass, placing them on their windows to listen to "ours", the Avseniks. The Avsenik brothers honed their artistry during this time, leveraging each new opportunity they could find.

\footnotetext{
${ }^{5}$ The Avseniks' albums, where Alpine and indigenous themes are already exposed in the title are: Tam, kjer murke cveto (1959), Klic z gora (1960), Stari mlin (1963), Lepe ste ve Karavanke (1965), Otoček sredi jezera (1968), Odmev s Triglava (1969), Auf silbernen Spuren (1970), Srebrne smučine (1973), Slovenija, odkod lepote tvoje (1974), Planinski cvet (1986), Muzikantje izpod Robleka (1988). The remaining albums are compilations of Avseniks' hits, every third song sings about the Alpine world and the lives of the local people. Other songs are focused on love, drinking, humoristic and occasional themes or mixture of them.
} 
Ultimately, their music became synonymous with the whole tradition (See Sivec 2010; Knific 2005b; Cvetko 2007: 52; Torkar 2008; Strašnik 2010; Galič 2012).

\section{AVSENIKS IN THE EYES OF OTHERS}

Among Slovenes, popular-national music is also called, somewhat pejoratively, "beef music" (goveja muska). Exactly why is not clear, though it may come from the tradition of listening to this music during Sunday lunches where beef soup is served, or the general association with Alpine regions where raising cattle has been an important agricultural activity. It may even come from an incident on the Slovene television where a film director, known for his sardonic wit, jokingly introduced an Avsenik recording by saying "Well, now let's do the beef!" Whatever the explanation, the term quickly gained currency, especially by those who were embarrassed to admit they listened to this music (Galič 2012).

This pejorative naming and other criticisms of their music are important as they highlight obstacles to the Avseniks more popular success. Many people within the music and media establishment were cautious, some to the point of hostility, towards the musical style. Publicly, many viewed this music as synonymous with provincialism, backwardness and conservative ways of living, but not the Avseniks. Vilko Ovsenik once explained his feelings on the matter:

Academically trained musicians tended to be against this music, because it was seen as profane and embarrassing for them. Some people can't stand the opera, others classical music, punk, rock or entertaining music. Different types of music have their audience who praise their beloved genre, and that's ok. But it's not right if the audience of one genre is against other music genres... Therefore, I have no objections if our music is named "beef music" or "farmers' music". I say: Whatever music we are doing, we must do it well! ${ }^{6}$ (Golica 2013)

Even as their success grew there were detractors who felt the Avseniks threatened "real" folk music. The editor of the "Thursday Evening with Local Songs and Tunes" radio show (Četrtkov večer domačih pesmi in napevov), Janez Bitenc, who launched the Avseniks in Slovene and world music circles, even arranged for a musicologist Rafael Ajlec to study the impact of the

${ }^{6}$ The statements quoted in the article are taken from interviews. The language has been proofread and adapted for the readers so as to keep the original message. 
growth of the Avseniks' style of music. In his report he defended the new genre, saying:

The need for popular-national music is demonstrated by the great interest of the radio audience for this new genre. It is very likely that other similar music groups, which would want to express in this style, will appear after the Avseniks. I propose such a program orientation, which will not inhibit the creation and continuance of this type of music, but at the same time it should sensitively monitor folk musicians so that the program would not fall in quality. (Sivec 2010: 40-41)

Popular-national music has its musicology critics who argue it overshadows "genuine" Slovene folk music, despite some competent musicians. They argue it has become a folk music for the masses that regularizes tastes, cultivates a false sense of rural life and makes listeners passive consumers.

One of the strongest criticisms is centred on the Avseniks' attire, Upper Carniola national costume - the obligatory companion of the popularnational music. The Avseniks decided to use it soon after their establishment and persisted with it throughout their careers. Vilko Ovsenik thinks that they would not use the costume if they had a better solution:

We said: if a symphonic orchestra has dark suits, we must have more light and merry colours. The man presents his image through dress as well. Moreover, the Upper Carniola national costume is very beautiful, really dignified... It is really happy, cheerful, a real suit for young boys. At the same time it is durable and gives the impression of neatness at any weather condition. (Sivec 1999: 103)

Slavko Avsenik says:

We came to it by accident. We wanted to have special outfits - they were made in Trieste, Italy - but they wrinkled so much that we decided national costumes are the real thing for musicians. You are always neat in it, never fully soaked in sweat. Playing in a bar is a different thing, but we were playing outside, in the sun and we sweated much more. Many people told us that the Upper Carniola national costume is one the most beautiful in Europe. Many Oberkrainers play in it. Hundreds of ensembles have used it to represent us and our music. (Sivec 1999: 60)

Their decision is not surprising. At the end of the $19^{\text {th }}$ century vocal and instrumental groups were already dressing in the costume. The region of the national costume used is also not much of a surprise, because the headquarters of the Avseniks is in Begunje in Upper Carniola. Moreover, the costume was established across Slovenia as a "folk uniform" or "national dress". Crit- 
ics of the Avseniks' attire mainly took the position that the Avseniks did not know the origins of the national costume. It developed in the $19^{\text {th }}$ century in an urban environment and later spread among the rural population, remaining in use in all social strata. The national costume, as understood today, does not show the appearance of the Slovene rural population, even if it is understood in this way. If the Avseniks felt that to successfully illustrate the appearance of folk minstrels and its underlying traditions, they would have to dress the part (Knific 2005a: 155-60).

Despite professional and lay criticism, popular-national music is not losing its popularity. Radio programs featuring the genre are popular, appealing to an enthusiastic audience (Robinšak et al. 2013). Listeners appreciate radio shows that combine modern and old popular music, short information and popular-national music. The desire for popular music amongst radio audiences is clear: ${ }^{7} 39 \%$ of listeners say they listen to popular-national music, $14 \%$ say they listen only to this genre. Only $7 \%$ of listeners express dislike for it. Importantly, consumers aged 15-30 lie above the average in their consumption of this tyoe of music (ibid.). Sašo Avsenik, Slavko Avsenik's grandson, shares his surprise that his grandfather's music is still alive after so many years:

It was a big surprise to us that this kind of music still fills halls after 60 years. Not tents, but concert halls where classical musicians usually play. This time they are filled with popular-national music. This is a big compliment from the public. (Kopina 2013b)

Some of Avseniks' popular-national songs became "folk songs", because of their popularity or frequency in the media. Mass frequency and numerous imitators who combine this genre with others (pop, rock), show that the foundation built by the pioneers of popular-national music was solid. The music has traversed the limits of the Thursday evening show. Today it is featured across radio and television, in public and commercial stations, and often in prime time.

\section{THE BEGINNINGS OF BROTHERS SLAVKO \& VILKO}

The brothers Vilko Ovsenik and Slavko Avsenik were born in Begunje in 1928 and 1929 respectively. They were steered towards music by their parents. The more independent, some might say stubborn minded Slavko, was a primarily self-taught accordionist, disliking formal music lessons, while Vilko

${ }^{7} 808$ people between 15 and 75 years of age from six Slovene regions were included in this research. 
followed a path to the Academy of Music in Ljubljana, studying the clarinet. In 1948 Vilko joined Radio Ljubljana's Big Band Orchestra, where he stayed until 1963 frequently playing with other ensembles as well. As Vilko was developing a reputation in the more established Slovene music institutions, Slavko was developing his own original approach to the accordion. Always praised and supported by his brother, Vilko encouraged Slavko to audition at Radio Ljubljana, where he was received with open arms. After popular success with Radio Ljubljana listeners, the show "Thursday Evening with Local Songs and Tunes" (Četrtkov večer domačih pesmi in napevov) was born. The independent streak in Slavko Avsenik is also evident in the different surnames of the brothers. Early in their lives, the local Priest in Begunje suggested to the brothers' father that they alter their surname to Ovsenik, which sounded more Slovene to him. The father accepted the suggestion and renamed all four children Ovsenik. However, Slavko did not agree and he wanted his old name back - Avsenik - the name now attached to the musical dynasty (Jercog 2008: 18).

As a performer Slavko was active in the band from 1953 to 1988, while Vilko stopped performing in 1959 due to health problems (complications from tonsillitis and an arm injury). Despite these problems Vilko remained the artistic leader, music producer and arranger of his brother's music. New melodies and songs using a variety of Slovene songwriters' texts were constantly coming from under Slavko's fingers. Vilko always ensured the arrangements and performances of these pieces by the Avseniks quintet were of the highest quality. Of particular importance to the brothers were the lyrics: good music also meant good lyrics. Over their career they cooperated with more than twenty inspirational songwriters, poets, writers and journalists like Fery Souvan, Elza Budau, Ivan Sivec, Ervin Fritz, Janez Menart, Ciril Zlobec, Tone Pavček, Gregor Strniša, Fran Milčinski - Ježek, Tone Fornezzi

- Tof, Svetlana Makarovič, and others (ibid.: 105).

\section{FROM MUSIC SUCCESS TO EXPANSION AND CONTINUATION OF THE TRADITION}

Historically the Avsenik family has run an inn - called Pri Jožovcu, since 1865. Today, this is connected with the musical tradition and is managed by Slavko's youngest son, Gregor Avsenik (1966-) with his wife Katarina. The inn is located next to their restaurant, which offers traditional Slovene fare, and accommodates up to twenty guests. In 1989 the art gallery Avsenik was opened by Slavko's second son Martin Avsenik (1962-) after he finished studies at the Academy of Fine Arts and Design in Ljubljana, inspired in no small part by the long-cherished love of painting of his mother Brigita Avs- 
enik (1932-). The German company Hohner, specialised in the manufacture of musical instruments, especially accordions, joined the gallery later, which was renamed Avsenik-Hohner Gallery. After Martin Avsenik went to work abroad, his mother, Brigita Avsenik, has taken over the gallery, which is blended with a museum. After a renovation of an old inn, the family opened a multipurpose hall "Avsenik Tradition" (Tradicija Avsenik) in 1997. In the beginning of 1999 they formed the Hišni ansambel Avsenik (Avsenik House Ensemble) which performs in Begunje and abroad. In 2003 the Avsenik Publishing house was created to maintain the records and albums of the Avseniks and publish new recordings of Avsenik music and other popularnational music ensembles. In 2008, on the $55^{\text {th }}$ anniversary of the original ensemble and Vilko's $80^{\text {th }}$ birthday, the family opened the Avsenik Museum, also in Begunje, which exhibits the Avseniks' records and golden records, awards, visual and documentary material, the interior of the Avseniks' home, their family tree, and offers souvenirs, including books, instruments or Upper Carniolan national costumes.

Additionally, the family also oversees the Avsenik Music School, where private music lessons are offered to 35 students who learn to play music and instruments (the accordion, trumpet, clarinet, bass, guitar, baritone and flute) typical of the Avsenik tradition. The Avsenik Music School offers a six-year module called Avsenik music with teachers who graduated from university programs majoring in music education or the instruments taught at The Avsenik Music School (Podpečan 2009: 9-19). The Avsenik Music School also organizes seminars and popular-national music workshops, as well the annual International Accordion Competition in Begunje for young people. The competition evaluates the style and technique of accordion playing, which is closest to the Avseniks. In addition, The Avsenik Music School publishes all the textbooks they need for music lessons.

As Slavko's son Gregor has said: "Maintaining the traditions and memories of the family is the most important value" (Pivk Avsec 2012). This commitment is found throughout the family. Slavko and Brigita's first son Slavko Jr. (1958-) is a professional musician. In 1981 he majored in jazz piano at The Academy of Music and Dramatic Arts in Graz, Austria, and in film and music composition at Berklee College of Music in Boston in 1985. He had composed and arranged many of his father's polkas and waltzes. Since 1998 he has been working at the Avsenik Audiodesign company, which specialises in music production and services. He described what, in his opinion, attracts audience to the Avseniks' music:

The characteristic of the Avsenik music is its extraordinary melody and dynamics; the emotion expressed through the music of Slavko and Vilko Avsenik is the one that is different. (Golica 2013) 
Gregor himself studied guitar at The Academy of Music in Ljubljana, but did not complete his studies, because he took over the family inn and ran his own ensemble (Ansambel Grega Avsenika) from 1996-2000. In 2009, Gregor's son Sašo, himself an accordionist who completed a secondary tourist school, began The Saša Avsenik Ensemble ${ }^{8}$ (Ansambel Saša Avsenika). With this, the third generation took the stage and today Sašo oversees the performances and recordings of his seven-member band.

\section{THE MILESTONES OF THE AVSENIKS' ROAD TO SUCCESS}

The Avsenik phenomenon began in 1953 with the establishment of the Trio Slavka Avsenika (The Slavko Avsenik Trio) which soon became the Gorenjski Kvartet (The Upper Carniola Quartet) in the same year, then the Gorenjski Kvintet (The Upper Carniola Quintet) in 1955. In 1957 it was renamed to Kvintet bratov Avsenik (The Avsenik Brothers Quintet) and finally in 1968 to the Ansambel bratov Avsenik (The Avsenik Brothers Ensemble).

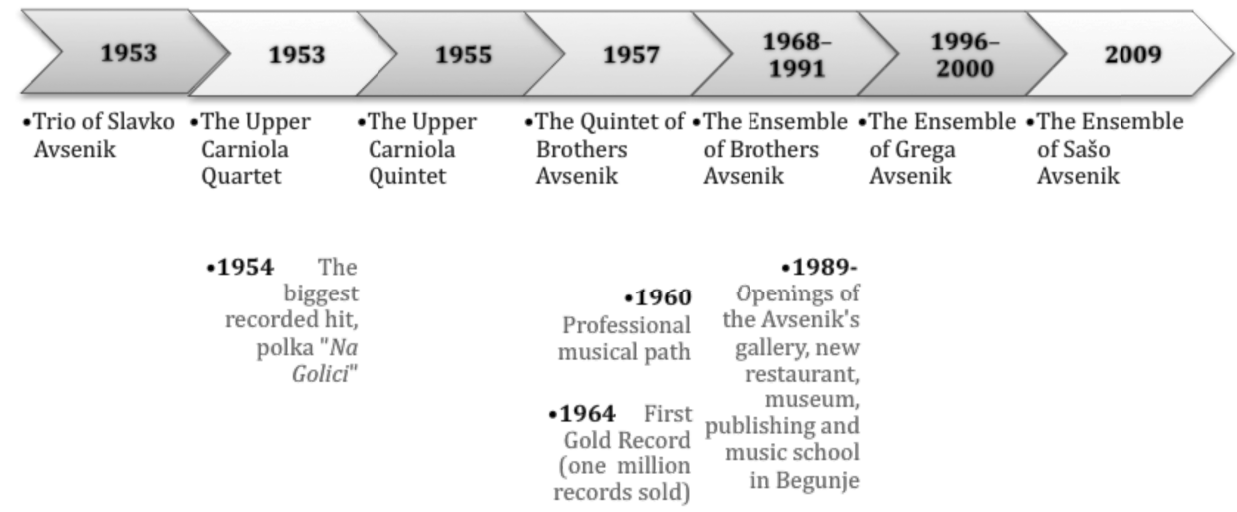

Illustration 1. Timeline of the three generations of the Avseniks' music tradition. Source: Mojca Ramšak

Slavko and Vilko's championing of this folk-derived genre have had a profound influence on the music of Slovenia and other Central-European countries for decades. In time, the hundreds of their original compositions became a central element of polka repertoires in Slovenia, America, Germany, Austria,

\footnotetext{
${ }^{8}$ His first name is Sašo, but the ensemble is formally appointed as The Saša Avsenik Ensemble. In the text I use the wrong declension, because it is the formal name of the band.
} 
Switzerland, and the Benelux countries, spawning hundreds of ensembles in the process.

The initial aversion in Slovenia regarding their German name (Oberkrainer Quartett), which was hurriedly given to themin 1955 by Telefunken because they did not want to publish their singles with a Slovene name, was overcome after 20 years of the Avseniks' work (Jercog 2008: 27; oral source Brigita Avsenik). In 1995, when the Avseniks were awarded their $14^{\text {th }}$ golden plate, they got The Linhart's Award (Linhartova plaketa) and had a performance on the New Year's Eve broadcast on TV Slovenia. In 1982 The Presidency of the Socialist Federative Republic of Yugoslavia awarded them with The Order of Merits for the People with Silver Star (Red zaslug za narod s srebrno zvezdo) (Sivec 2010: 178-179). They also found fans amongst politicians who benefitted from their development and increased their reputation. For instance, they played ten times for the former president of the Socialist Federative Republic of Yugoslavia, Josip Broz Tito, and won various state awards. The Avseniks have performed before millions - including heads of state - on radio and television, and in thousands of concerts nationally and internationally. Their tours lasted months on end, and they sometimes performed several times per day. They were the only music group who performed a solo concert in the Berlin Philharmonic. These facts had a favourable impact on the Avseniks' development and reputation, but it did not change them significantly.

The most important factors on their music path can be summarised as follows:

- Family encouragement and support;

- Historical conditions and social systems after World War II, especially that of the former Yugoslavia, including:

a) Postwar economic growth and optimism because of the rebuilding of the country;

b) Market demand for entertainment music connected with a "traditional rural life";

c) Expansion and proliferation of communication technologies in Slovenia and across Europe (particularly radio and recording technology);

d) Rapid development of the music industry in Europe and globally;

e) Rapid development of social and industrial infrastructure and migrations of rural populations into the cities;

- Engagement with influential and established institutions (e.g. Radio Ljubljana) in the media industry nationally and internationally;

- Commitment to the cultural legacy, including local folk musicians, from which they originated (See Sivec 2010; Cvetko 2007; Strašnik 2010; Rossiter et al. 2011). 


\section{THE AVSENIKS' BUSINESS MODEL}

The Avseniks' business model evolved from truly humble beginnings, and they learned as they went. At first, their performances were an enjoyable side-business to more regular employment - they operated almost as buskers, collecting money from around the audience. This was changed by Vilko Ovsenik, who considered that they have to be more professional and deal with the financial aspects of their profession.

Such practice resembles the activity of folk minstrels or folk musician (ljudski godci), gifted individuals, who played to earn additional money for survival. Paying the minstrels was ordered by customs and agreement in advance. The logic of the profit of folk minstrels was simple - the better and more amusing they were, the more they made (Cvetko 2007: 20). As the Avseniks became ever more successful and popular, they began to operate more professionally, charging entrance fees for performances, and guarding against unscrupulous record producers or agents. As distinguished from the minstrels who were performing individually or in very small groups, the Avseniks performed as an ensemble. Their reputation also distinguished them from the minstrels. ${ }^{9}$ The minstrels were believed to be less serious musicians who shirked their responsibilities; the Avseniks were successful musicians with an international reputation. The time was ripe for real entrepreneurship, and so in 1960 the ensemble decided to perform professionally. Their careers became lucrative despite their slight distaste for business formalities.

They sensed their opportunity in the development of recording technology, the possibilities of studio recordings and the demand for popularnational music in the "Thursday Evening with Local Songs and Tunes" radio show (Cvetko 2007: 38, 52). After that they needed another 15 years to develop from these humble roots to performing for millions.

In addition to their devotion to music and the favourable external condition they were able to leverage, the Avseniks developed a highly attuned sense of their audiences and a responsibility to them and an utter obsession with performance perfection. Slavko Avsenik and Alfi Nipič, the singer in Avseniks recalls:

You need to respect the audience. To come sober, prepared and well-trained. I must admit that we all had this attitude. Everybody prepared before the concert to give the maximum of himself or herself on the stage. (Golica 2013)

${ }_{9}^{9}$ Popular-national music ensembles are a new phenomenon with new content (e.g. instrumental music, performances by women, the production of audio media) and at the same time they continue the old folk musician traditions (reintroduction of the diatonic accordion, creation and performance of folk melodies). The Avseniks' music knowingly or unwittingly imitates rural folk musicians and coming back from whence it came in the folk music tradition (Kumer 1978: 375, 377-378). 
The Avseniks were complete professionals and perfectionists from the start to finish. Their performances were polished to the second and to the millimetre. We came on stage exactly on time, we knew exactly where to stand, when to move forward and when to withdraw, when to step behind the instrument and when to vocally support the instruments. Everything was well thought out to the point of perfection, as the audience immediately noticed when anyone acted unprofessionally. You had to come energetically, get it done and get out. (Nipič 1996: 15)

Of course, behind their growing popularity and success lay an entrepreneurial spirit, which laid the organizational and business foundations for their future. Their entrepreneurial drive was fuelled by their intrinsic motivation to perform and achieve the highest standards of music-making and composing. Yet they were also bolstered by, and successful at leveraging, the economic development and growth in the former post-war Yugoslavia, where living conditions and social security were becoming increasingly stable.

The Avseniks learned how to commercialize, leveraging this in their favour and creating a visionary enterprise. They focused on gathering insights and intelligence from their industry. For example, Vilko Ovsenik systematically listened to and took notes about all the characteristics of the recordings preferred by listeners and studied the length of the songs. Two or three minutes-songs became the norm in popular-national music. The Avseniks paid attention to the wishes and needs of the audience while performing on the stage, where they, depending on the response, arranged or skipped some songs, or repeated favourites. In their professional phase, they carefully planned their performances and took care that the programme would not be the same in the same place or that there would be at least a year in between performances. They eventually went on to add other elements to their concert performances, such as moderators or humorists ${ }^{10}$ to set them apart, and with this they created the music show. One of the Avseniks business moves, which they copied from foreign musicians, was the fixed date of their yearly double album, which was a month and a half before New Year, when holiday shopping began. Other marketing opportunities they capitalized on included publishing records before the Sarajevo Winter Olympics of 1984, building a hype around their anniversaries, recording themed albums for special interest groups such as mountaineers, skiers and hunters as well as albums in German. They also republished their songs with new arrangements and thus maintained a constant presence in the local market, among the Slovene immigrants in the USA or in Europe (Sivec 2010; Strašnik 2010).

${ }^{10}$ The trumpet player Franc Košir, the humorist Vinko Šimek in the role as Jaka Šraufciger, Tone Fornezzi - Tof in the role of a journalist, Mito Trefalt, etc. (Sivec 2010). 


\section{THE AVSENIKS' LACK OF ATTENTION TO THE BUSINESS ASPECT OF THEIR ENTERPRISE}

Especially at the beginning of their career they did not pay much attention to their intellectual property rights and hidden pitfalls of contract terms.

Twice, they were even accused of copyright infringement by mistake. For instance, they were wrongfully accused of breaking copyright law with one of their most beautiful and popular waltzes Tam, kjer murke cveto (Where the murke flowers blossom) ${ }^{11}$ and Rezka (Terry), both written in 1957. The waltz "Murke" was used by Jonny Pecon and Frank Jankovic, "the king of polka" in the USA, who copied it unintentionally because they believed it was a national folk song, and recorded it as Lullaby - a highly successful song in the US. The case went to court and in 1970 the Americans apologized to Slavko Avsenik. The intellectual property was clarified, however financial compensation was never resolved; Lullaby was very successful in America. More than the loss of royalties the Avsenik brothers suffered from stained reputation. In another case, the waltz Rezka also suffered an attack, but a journalist from Trieste, Saša Martelanc, clarified the matter in one of his own articles (Jercog 2008: 34-35).

When The Avsenik Brothers Ensemble was at its peak - touring and performing up to five times per day, 330 days per year - their official and behind-the-scenes managers arranged their appearances and dealt with things like responding to fan mail. In 1955, their first manager Rudolf Kempf from Germany, came unannounced to Slavko Avsenik's flat in Ljubljana with posters printed in advance announcing a thirty-day tour in Bavaria. As the other members of The Upper Carniola Quartet (Gorenjski kvartet) were occupied with their other jobs, Slavko was accompanied by three young German musicians on the tour. All his performances were highly successful, but he only earned 200 German marks for his efforts and he performed under the name Oberkrainer Quartett (so named by the Bavarian audience members). This name stuck, though Slavko was not happy with it, and their first record, recorded in Germany, came out under this German name. He started to seriously consider leaving his job in the Tonosa factory in Ljubljana and become a professional musician. Despite the success of this album, and the admiration of their fans, the Avseniks' were again the victims of an unfair contract and they earned only 700 German marks from the record sales. ${ }^{12}$ Moreover, the album featured the Avseniks' greatest hit ever, "Na Golici" (Jercog 2008: 26-27; Golica 2013).

${ }^{11}$ Murke (lat. Nigritella), flowering plants from the orchid family, frequently found in the Alpine regions of Europe.

12 This album was the highest selling album of the genre to date. 
Brigita Avsenik, Slavko Avsenik's wife, who was a behind-the-scenes leader, recalled:

As far as the contractual stuff, neither my husband nor his brother Vilko had much insight into it. They signed everything and they were pleased to have the work and the success. Neither of them was conscious of the terms of contracts. In general, various companies made a great deal of money off them. My husband has some royalties, which are lower than they were in the previous years, because his music is not played as much as before, when they were still active. (Prava ideja 2013)

In 1958 the Avseniks changed their manager. Rudolf Kempf was replaced by Karl Lanzmeier from Austria, who stayed in this position until the original ensemble stopped performing publically in $1990 .{ }^{13}$ Lanzmeier devoted all his energy to the artistic success of the Avseniks. It is uncertain whether the band would endure together for so long had it not been for this connection. Karl Lanzmeier, the manager, remembers:

In December 1958 I had my first concert with Slavko's Oberkrainers in Leoben. We signed a contract a year earlier in Begunje. The period from 1954 onwards had not been competitive, but people always imitated what is good. Many groups tried to imitate Slavko. The competition was not felt, the tour only had the Avseniks. All, from independent musicians to the orchestra musicians, played "Na Golici", Slavko and Vilko’s melody. (Golica 2013)

\section{THE “NA GOLICI” HIT: THE AVSENIKS' RISING STAR}

The Avseniks' future success was perhaps most clearly triggered by their first, and arguably greatest hit, "Na Golici" (Trumpet Echoes). Written in 1954, the polka became the group's trademark calling card. The melody came to Slavko during a night shift while he was working at a Ljubljana sock factory (he worked there from 1952 to 1956). Surrounded by the deafening rhythm of industry, he began to imagine the echo of the Begunje church bells under the Golica, a mountain on the border between Slovenia and Austria. The melody he conjured up fused with the rhythm of the knitting machine Slavko was running: "di-dah-di-di-di-dah-di-di-di-dah-di-di-di-dah". The combination of sounds in his mind and imagination brought forth Na Golici's "para-rara-pararara-parararararam". Feverishly he scribbled the music on a paper bag using

\footnotetext{
${ }^{13}$ Between 1991 and 1994 The Avsenik Brothers Ensemble continued its work as a studio band and they recorded three albums in this period.
} 
his own method of noting sounds. "But something is still missing", he said to himself, struggling to balance the first two parts of the song with a final, quick section. Suddenly he had an idea and dashed this down as well. Though he doubted the song's worth - typical humility for Slavko - the next day he played it for his brother. Vilko listened with enthusiasm and recognised the hit quality of the song and set about arranging it for the quintet. He declared: "Almost a perfect song! There is nothing much to add or improve. We have to record it in the way that a trumpet and a clarinet talk to each other." And Slavko said to Vilko: "Do you know what I imagine when I listen this song?" And Vilko answered him: "I know. An echo of Begunje bells... under Golica". From their intuitive collaboration the new polka was immediately recorded at Radio Ljubljana and became a hit. It became so popular, in fact, that for years the Avseniks began every performance with it and always delighted the audience with requested repeat performances. Since its birth, "Na Golici" has been recorded in more than 600 versions by other musicians (Jercog 2008; Golica 2013; Sivec 2010: 42, 257). The centrality of this product of the success of the Avseniks was recounted by Slavko, his son Gregor and grandson Sašo Avsenik in 2013 in a television documentary about the song's origins and its impact:

I will never forget how we played at a fête in the garden at home in Begunje. Young people were in the trees for hours, it was unbelievable, and they wanted to listen to Golica and nothing other than Golica. It was a miraculous piece. Golica was a sensation for all musicians. (Golica 2013)

I think over and over again, that Golica is a phenomenon in itself and an incredible success as an instrumental composition, which competes with all the vocal hits. And again, all performances begin with Golica. It is a guarantee that as soon as an ensemble or a group takes to the stage, it hits the audience making an immediate connection. It's a guarantee, which we somehow exploit again and again. (Golica 2013)

It is the third generation of the family musicians that has been influenced by Golica. It becomes our everyday life; we hear it or see it on the radio or television every day or we play it ourselves. We always start every performance with Golica and end our shows abroad with it. This song is always demanded. When we go to the European market, they call us Oberkrainers, this is automatically this genre and its queen is Golica. (Golica 2013)

In the light of "Na Golici" and the increasing demand for their music and performances, the quintet began playing their own live shows in 1959. By 1960 they felt ready to give up their other jobs and fully devote themselves to the Avsenik musical path. 
When we broke through, for instance, in Switzerland, all Saturdays and Sundays were booked four years in advance for fêtes, etc. This gave us the courage to leave our jobs and become professionals. Our greatest luck was that we could play so much in Germany, Austria and elsewhere, in order to survive. (Avsenik 2009)

In the ensuing years the Avsenik brothers wrote and arranged almost 800 original compositions of vocal and instrumental music, sold over 36 million records and played over 10,000 live shows. They have been honoured with several awards, including: 31 gold records, 1 diamond record, 2 platinum records, the European Musical Oscar, the Golden Rose for most frequently played ensemble on Austrian radio programs, the Silver Star of merit in the former Yugoslavia, the Victor Award for their life's work in Slovenia, the Order of Freedom of the Republic of Slovenia. The Slovenian Post has even made an Avsenik stamp and the Guinness Book of World Records lists them as the most successful ensemble in their genre of music. Perhaps closest to the hearts of Slavko and Vilko are the hundreds of Avsenik fan clubs that have grown worldwide ${ }^{14}$ and the scores of musicians that have taken up and furthered the Avsenik sound nationally and abroad (Jercog 2008: 108-109).

\section{ON THE STAGE AND BEHIND THE SCENES}

The Avsenik Brothers Ensemble had two behind-the-scene leaders: Vilko Ovsenik, who had to stop playing the clarinet in the band in 1959, because of health problems, and Brigita Avsenik, Slavko Avsenik's wife, who also had a music education and played the piano in the family inn before she met her husband. Vilko Ovsenik, a formally educated musician, arranged and orchestrated his brother's compositions, except when he was serving in the army, wrote notes for different music arrangements, oversaw the quality of performances and the ins and outs of the group's performers. He also professionally led studio recordings, worked as a co-producer, searched for new sound effects and new musical opportunities. Though Vilko oversaw much of

${ }^{14}$ There is a narrative story of a Japanese manager for the Mitsui Group, Yoshiya Watanabe, who came to Begunje every year to meet the Avsenik family. He was dressed up in the Upper Carniolan national costume and played the Avseniks' music in a German restaurant in Tokyo, where he had a collection of their records and CDs (oral source Dr. Danica Purg). The second example of their international fame is the story of the big surprise, experienced by the former Slovene President Dr. Danilo Türk when he participated the OECD World Forum in Busan, Korea in 2009. After he was welcomed with presidential honours, the orchestra first faintly played something that should have been the Slovene national anthem. At the end of the official part, the orchestra suddenly, at full power and with as much zeal hit Avsenik's Golica, in a way that the President had never heard (Jež 2015). 
the performing and recording, the members of the ensemble had the right to personal creative collaborations, which is a core reason for the success of the ensemble and the satisfaction of the musicians involved (Jercog 2008: 31; oral source Brigita Avsenik). Brigita Avsenik, who rarely accompanied her husband on tours, was taking care of the communication with the Avseniks' fans and arranged performances at home. At times she would also help Vilko with the arranging and orchestrating, copying down the notes he dictated. She also had an overview of the contracts and in later years took care of the Avseniks' enterprises in Begunje, especially the art gallery.

The interplay between Slavko Avsenik as an inspirational, charismatic, energetic and confident musical leader of the band (especially on stage) was supported by the formal management, family members, and the members of the band. This formed a professional entity based on family values and musical excellence. The management and leadership always took on a shared nature, distributed across all of these individuals; over-confidence or arrogance was actively discouraged. All members of the Avseniks' team were involved, engaged and committed to their shared goals and purpose of high-quality music-making. Slavko Avsenik, who was perceived in public as the engine of the ensemble, never forgot to mention the contributions of his brother, wife and the whole ensemble. The same was true of his brother Vilko, who praised Slavko's talent, Brigita's diligence and her invisible presence. The manager, Karl Lanzmeier, who himself did not have any children, devoted all his energy to the success of artistic expression and development of the Avseniks. If this connection had been lost or loosened, it is uncertain whether the band would have endured together for so long. Many singers and musicians in the band stopped performing with the Avseniks for different personal reasons, but no one ever abandoned the group because of a troubled or problematic relationship with any of the - visible or behind-thescenes - leaders. ${ }^{15}$ The Avseniks were able to maintain a closely connected group who shared information with each other, and understood the ideas, perspectives, and progress of everyone else. These have been the most important ingredients of their success for 60 years. Karl Moik, the host of the Musikantenstadl TV show, remembers:

Slavko has achieved his success with a wonderful team. Vilko was a dream arranger. Musicians and singers were professionals. Perfect music can be created only by professionals. This is an old secret. If you have keen musicians, the music goes into your ear. To me that has always seemed logical. Slavko Avsenik always knew how to impress the audience. (Golica 2013)

\footnotetext{
15 There were 35 musicians and singers who performed with the Avseniks over the years.
} 
Sašo Avsenik describes how his gradfather advised him about leadership strategies:

When I came to grandpa for advice, he helped me a lot. Also with advice on how to lead the ensemble, because he was a very good boss. I liked it that the boss should not have the money, so in my group my musicians (in Saše Avsenik's ensemble, note M. R.) take care of the finances and share the salary. We have control and I would never take any commission. In our band the guitar player takes the money and then he shares it. (Kopina 2013b)

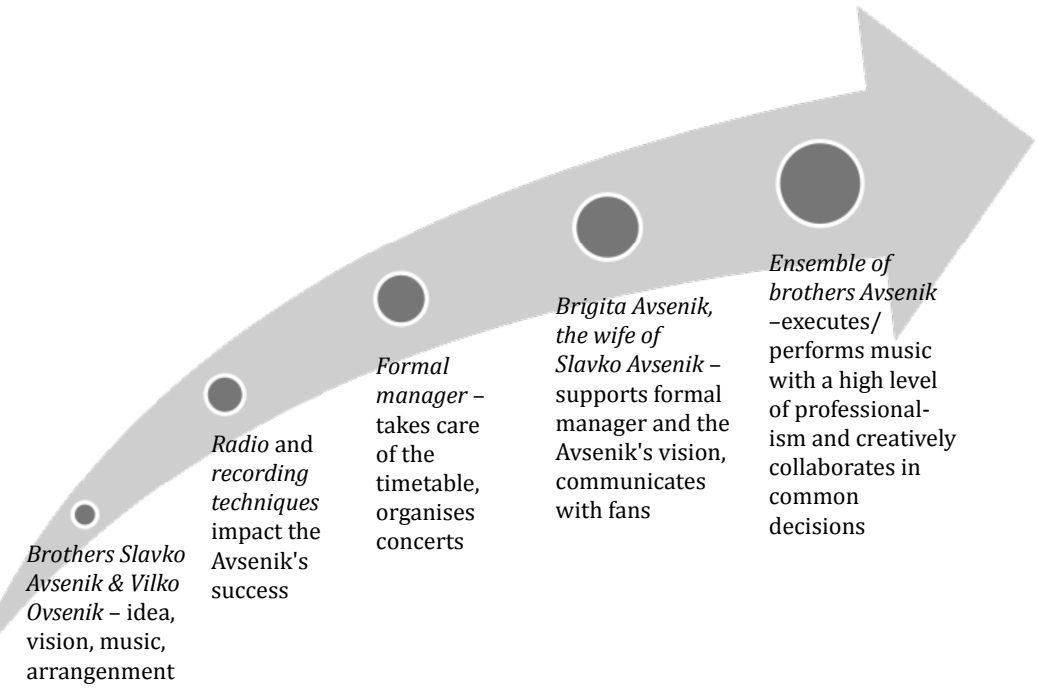

Illustration 2. Steps of the Avseniks' workflow and the distribution of leadership strategies and approaches. Source: Mojca Ramšak.

\section{THE YOUNG AVSENIKS - THE SAŠA AVSENIK ENSEMBLE}

Sašo Avsenik, Slavko's grandson, decided to become a professional accordionist. He saw more opportunities in the popular-national music ensemble than in rock music with which he had been involved. In 2009 he established The Saša Avsenik Ensemble.

I never thought I would become a professional accordion player, because I have training in tourism. Our first ensemble in secondary school included the drums, but this story didn't end well, because it was difficult to get members. We said we were going to have a rock group and the boys already saw beer and young ladies. But when we started with popular-national music social 
gathering were in focus: you go to a party, you play and have fun. We started to play popular-national music spontaneously. (Kopina 2013b)

The group's premiere was in November 2009 in a television show called Muzikantenstadl (Hay barn with minstrels), broadcast live in Germany, Austria and Switzerland. At the same time the young Avseniks wanted to do studio recordings and soon they recorded three CD's (Na sončni strani AlpOn the sunny side of the Alps, 2009; Zavrtimo se - Let's turn around, 2011; Dolge so noči - The nights are long, 2014). The albums include new arrangements of familiar Avsenik songs as well as new ones written by Slavko and arranged by Vilko. The Avsenik brothers joined their creative forces after 20 years to help the third generation of family musicians and Sašo Avsenik proudly states:

My Grandfather was very proud and happy when he saw me for the first time with the accordion and in a national costume. Grandparents wish their grandchildren to take over something from them. Grandpa surprised me, because he was so proud of me, but he never forced me to it. He gave me an open hands. People sometimes ask me: "Did grandpa say you have to do it?" But in fact, he allowed me to choose freely between tourism, sports and music. He went his way and he let me find mine. (Kopina 2013b)

The Saša Avsenik Ensemble performs 170 times per year, 110 times of it abroad. They have visited Germany, Austria, Switzerland, Italy, France, Netherlands, Croatia, Belgium and Canada on their concert tours.

Today The Saša Avsenik Ensemble has seven members, and Saša's father, Gregor Avsenik joins them occasionally. The group has a German manager who runs the administrative and logistical side of their work and they rely upon an agency for professional representation. Because the young Avseniks also focus on German speaking audiences, since 2012 they have also been known as Sašo Avsenik und Seine Oberkrainer (Sašo Avsenik and his Oberkrainers). This was an intentional, market- and brand-oriented decision for the younger generation as opposed to the older generation.

The Saša Avsenik Ensemble entered the music industry with considerable cultural capital. They enjoy name recognition, musical heritage of the Avseniks and the financial support of the family. Saša quickly adapted to the demands of the market. He invited Jurij Zrnec, an actor in the Slovene National Theatre Drama Ljubljana, to vary their programme with stand-up comedy. He has a similar role as the trumpeter Franc Košir in Sašo's grandfather's ensemble. Their formula for success is based upon the selection of the best, and adapting to have proven music and entertaining contents; they act from their knowledge of the mass-music taste, technology, and orient themselves towards youth and urban life. As Sašo Avsenik said: 
We also found musicians on Facebook. Then we held an audition and came together. There are Styrians, Upper and Lower Carniolans and Carinthians in the group. Slavko and Vilko are cooperating, too, as well as my father Grega. The texts are by Ivan Sivec. We try to get the best and cooperate with the best. (Golica 2013)

Our audience is mostly young people, abroad the audience is still from my grandpa. (Prava ideja 2013)

\section{CONCLUSION}

Close family ties, a clear vision and a professional attitude were rewarded with great success. In the Avseniks' case we cannot really speak of a clear strategic plan. If we talk about their music development, they were learning by doing and by observing the audience's response. This tactic had its benefits and drawbacks. It was primarily an intuitive process from which much can be learned about creativity and innovation in the music and cultural industries. Later, they used new technologies and recording opportunities, paired with the desire for popular-national music, which was warmly received by the radio audience. There were, of course, lucky circumstances, finding themselves in the right place at the right time, which enabled higher recognition on the stage. As Slavko Avsenik Jr. said:

The Avseniks' music developed for 60 years. 60 years of learning from the audience and cooperation with the audience on their own way. (Kopina 2013a)

Through time and experience, the Avseniks developed supportive behaviour for all involved in their ensemble, a strong commitment to quality control, organizational spirit, entrepreneurial initiatives, persistence and self-confidence in individual and organisational performance. The family members were the strategic movers and performers at the same time, and formal and informal managers were there to help realise at least some of their dreams. They also learned from their mistakes, especially in terms of their naivety and trusting the wrong people who many times benefited from their music and performances.

The Avseniks' business plan, strategic management and leadership - although they were not formally recorded - are the model on which we can observe and learn about the existence, growth opportunities and pitfalls in creative music industries. Their multi-generation business model strategy can be summed up in three parts: 
1. Mission (create and play high-quality popular-national music, entertain and inspire the audience);

2. The long-term vision (building the Avsenik brand in Slovenia and abroad, presenting Yugoslavia and Slovenia to the world);

3. Strategic management and leadership:

- Work (motivation and a sense of belonging, writing and playing music, creativity, professionalism, organisation of work, collective decisions and cooperation, commitment)

- Marketing (knowing the market, musical tastes and music technologies, marketing their music and music products, the integration of family and official managers in sales)

- Earnings (living with their own music).

Avsenik strategic risks can be broken down as follows:

- Internal (feeling the demand to constantly be the best and creative, work to the fullest, being closed to external musical innovation, the balance between family musical tradition and new musical tastes, fixed costs of maintaining and expanding the Avsenik brand);

- External (naivety when signing contracts, and working for a small fee at the beginning of their career, competition - the great number of popular-national music groups, the saturation of the market, new technologies with access to free music, the development of the entertainment industry).

However, through dedication, charisma and pure hard work, the Avseniks became a tremendous musical success, perhaps less so commercially, but they have provided much to their community, the Upper Carniola region, their native Begunje and Slovenia. They became a musical voice of Slovenia and the wider Alpine traditions. Where will they go from here? Will the young Avseniks remain as charismatic as The Avsenik Brothers Ensemble in attracting the media, fans, filling concert halls, impacting their followers and the music industry?

Sašo Avsenik, the third generation musician, sees the future as a combination of the old and the new, of tradition and modernism. His measures of success are a combination of innovation, recognition and commercial prowess:

It's interesting how popular-national music is developing. I think it's important, that we cherish the tradition - save the sound that was - and think about the young and modernise as well. The Austrians do that. The Balkan Severina does it. She brings in buglers (trumpeters), connects tradition with popular music and adds commercial value to the music - well-thought out... I would like to discover a sound that I could call my own. This is one of my many goals. The second goal is, to find harmony between the traditional and modern genre, not to hurt older audiences and not to be boring for the young popula- 
tion. The third wish is, to create a song, which would be sung in the streets... There are a lot of musicians who would like to play like the Avseniks. They want to copy. Even if I would want to play like my grandpa, we know that this is impossible. Therefore, I say, copying makes no sense; you have to do things differently. When we play with my ensemble, we want to come close to the recordings and not to change the melody or the music message. Of course we add our own elements into the music, so that when you hear our music and the Avseniks recordings, you notice the difference. That is Slavko and this is Saša Avsenik. Of course, my Grandpa is much better... We are lucky that there is a strong tradition behind our name. (Kopina 2013b)

The Avsenik brothers management challenge was in a largely intuitive testing process which is a good fit for music-related creativity and innovation. The questions: could the Avsenik brothers have taken a more strategic approach to where they were headed with their music?, And could they have also developed a business plan for what they were hoping to do?, remain unanswered. They created a successful business out of love of traditional music. The power of passion and commitment to their ideals provided a sound foundation for success. Their almost improvisational nature of tactic and planning was very appropriate for creativity and innovation within the music industry. However, innovative, emergent planning had the need for more of a strategic focus on the part of the brothers. It was developed with the help of the Avseniks' managers. There is no one answer if more traditional strategic thinking really has a role in the arts - or whether the planning process should emerge from the same type of creative, innovative approach used for the music itself. The most appropriate way to strategically create a plan for such businesses depends on many conditions. This type of music industry is not necessarily destined to be run along the lines of what the two brothers did - improvise along the way, guided by their passion and commitment to the music. It could be planned ahead, but the question is, if such strategic planning also brings the same music success and charisma. Only time will tell if the third generation with a clear strategy will achieve the same music success as their predecessors.

\section{REFERENCES AND SOURCES}

Austin, Robert D. 2007. Paul Robertson and the Medici String Quartet (Case Study 9-607-083). Boston, Massachusetts: Harvard Business School, 1-17.

Avsenik Slavko: “Če nas lahko kdo ujame, je to moj vnuk!” Ob častitljivem jubileju smo se pogovarjali z glasbenikom. 2009. Ljubljana: MMC RTV SLO, 26. 11. Available at: http://www. rtvslo.si/zabava/druzabna-kronika/slavko-avsenik-ce-nas-lahko-kdo-ujame-je-to-mojvnuk/217764 (accessed 9 April 2014). 
Banahan, Eoin and Jim Playfoot. 2004. Slovenian National Orchestra (Case Study UVAOB-0838). Charlottesville, Virginia: Darden Business Publishing, University of Virginia, $1-10$.

Chakravorti, Bhaskar, Janet Kraus and Shirley M. Spence. 2012. Blue Man Group. Creativity Life and Surviving an Economic Meltdown (Case Study 9-810-108). Boston, Massachusetts: Harvard Business School, 1-25.

Cvetko, Igor. 2007. Zvoki Slovenije: od ljudskih godcev do Avsenikov: razstava, Slovenski etnografski muzej, 22. november 2007 - september 2008 = Sounds of Slovenia: from folk musicians to the Avseniks: the exhibition by The Slovene Ethnographic Museum, 22 November 2007 - September 2008. Ljubljana: Slovenski etnografski muzej.

Eterović, Ana. 2008. "Folklorizem za novo rabo. Ljudska, narodno-zabavna, turbofolk". [Bachelor's thesis]. Ljubljana: Univerza v Ljubljani, Fakulteta za družbene vede.

Ferbežar, Ina. 1995. “Besedila Avsenikovih narodno zabavnih popevk 1953-1985 ali popevčice milemu narodu". Traditiones 24: 331-339.

Galič, Jože. 2012. Narodnozabavna glasba - je res "goveja"? SIGIC, Slovenski glasbenoinformacijski center, 9. 3. Available at: http://www.sigic.si/slovenska-glasba-po-zanrih/ narodnozabavna-glasba (accessed 3 December 2013).

Golica, zgodba o skladbi. Zgodba o Ansamblu bratov Avsenik (dokumentarni film). 2013. RTV SLO 1, 23. 10. Available at: http://www.rtvslo.si/moja-generacija/rtv-zame/priporocamo/oglejte-si-igrano-dokumentarni-film-o-legendarni-golici/320806 (accessed 10 November 2013).

Jercog, Aleksi. 2008. S polko v svet. Glasbene poti bratov Avsenik. Begunje: Avsenik.

Jež, Boris. 2015. "Sporočilo otrok iz Beaver Creeka”. Delo, 16. 2. Available at: http://www.delo. si/mnenja/blogi/sporocilo-otrok-z-beaver-creeka.html (accessed 18 February 2015).

Juvančič, Katarina. 2004. "O (ne)moči izvirnega. Resonance avtentičnosti v poustvarjanju slovenskega ljudskoglasbenega izročila”. Glasnik Slovenskega etnološkega društva 44/2: 14-22.

Juvančič, Katarina. 2005. "The Popularization of Slovenian Folk Music between the Local and Global. Redemption or Downfall of National Heritage". Traditiones 34/1: 209-219. [http://dx.doi.org/10.3986/Traditio2005340117]

Knific, Bojan. 2005a. "Kostumiranje narodno-zabavnih ansamblov". Traditiones 34/2: 155177. [http://dx.doi.org/10.3986/Traditio2005340209]

Knific, Bojan. 2005b. "Slovenija, od kod lepote tvoje. Narodno-zabavna glasba kot sooblikovalka sodobne slovenske popularne kulture". Glasnik Slovenskega etnološkega društva 45/12: 73-77.

Kopina, Klavdija. 2013a. "Bila sva mlada oba: Avsenikova glasba ni zagotovilo za uspeh, a je v pomoč. Prvi narodno-zabavni muzikal z glasbo ansambla bratov Avsenik". MMC RTV SLO, Ljubljana, 8. 9. Available at: http://www.rtvslo.si/zabava/druzabna-kronika/bila-svamlada-oba-avsenikova-glasba-ni-zagotovilo-za-uspeh-a-je-v-pomoc/317151 (accessed 9 April 2014).

Kopina, Klavdija. 2013b. "Sašo Avsenik: Seveda je star ata veliko boljši!” MMC RTV SLO, Ljubljana, 10. 5. Available at: http://www.rtvslo.si/zabava/druzabna-kronika/saso-avsenikseveda-je-star-ata-veliko-boljsi/308350 (accessed 9 April 2014).

Kovačič, Mojca. 2014. "Kje so ljudski godci? Refleksija preteklih konceptov in možnosti novih opredelitev ljudskega godčevstva”. Glasnik Slovenskega etnološkega društva 54/3: 12-19.

Kumer, Zmaga. 1978. "Godčevstvo in sodobni instrumentalni ansambli na Slovenskem". In Pogledi na etnologijo. Angelos Baš and Slavko Kremenšek, eds. Ljubljana: Partizanska knjiga, Filozofska fakulteta, 365-378. 
Marttila, Kalle. 2012. Musicians as Entrepreneurs. [Bachelor's thesis]. Degree Programme in Music Management School of Business and Services Management. Jyväskylä, Finnland: Yamk University of Applied Sciences.

Marty, Maša. 2007. “Jodlanje. Nov način petja na Slovenskem?” Traditiones 36/2: 67-76. [http://dx.doi.org/10.3986/Traditio2007360204]

Muršič, Rajko. 2000. Trate vaše in naše mladosti. Zgodba o mladinskem rock klubu. Ceršak: Subkulturni azil.

Nipič, Alfi. 1996. "Rečeš. Servus, kak ste kaj, in prisedeš - Pevca Avsenikov intervjuja Nada Ravter". 7D, 27. 11., 15-17.

O’Donnell, Shannon. 2011. “The Towards Silence Project. Multiple String Quartets Organize to Perform a new Musical Form in Spatially Variable and Distributed Conditions". (Case Study 3). Journal of Business Anthropology. Autumn 1-21.

Pivk Avsec, Saša. 2012. “Avsenikov muzej. Harmonika in žup'ca”. Slovenske novice, 25. 3. Available at: http://www.slovenskenovice.si/novice/slovenija/avsenikov-muzej-harmonikazupca (accessed 1 December 2013).

Podpečan, Igor. 2009. Osnovno glasbeno izobraževanje, modul Avsenikova glasba. Begunje: Glasbena škola Avsenik.

Prava ideja, Blagovna znamka Avsenik. 200. oddaja - Slavko, Gregor in Sašo Avsenik in voditeljica Edita Cetinski Malnar. 2013. RTV SLO 1, 3. 10. Available at: http://www.rtvslo.si/pravaideja/novica/730 (accessed 10 November 2013).

Robinšak, Matjaž, Alenka Pfajfar and Uroš Gjerek. 2013. Odnos poslušalcev do programskih vsebin: Poročilo. Ljubljana: Agencija za pošto in elektronske komunikacije Republike Slovenije, Valicon.

Rossiter Nancy E., Peter Spang Goodrich and John Shaw. 2011. "Social Capital and Music Entrepreneurship". Journal of Management and Marketing Research 7. Available at: http:// www.aabri.com/manuscripts/10660.pdf (accessed 13 December 2013).

Saintilan, Paul. 2013a. "Crisis in the Opera House. An Artist Relations Case Study". (Case Study 1). In Paul Saintilan, JF Cecillon, Michael Smelie and Rob Cannon. Music Organisation Case Studies. For students studying music organisation in arts management or music business programs. Melbourne, Australia: Australian College of the Arts.

Saintilan, Paul. 2013b. "Government Funding of Music Organisations - Vital or Dysfunctional?" (Case study 6). In Paul Saintilan, JF Cecillon, Michael Smelie and Rob Cannon. Music Organisation Case Studies. For students studying music organisation in arts management or music business programs. Melbourne, Australia: Australian College of the Arts.

Saintilan, Paul. 2013c. "The Artistic v. Interfunctional Conflict Case". (Case study 4). In Paul Saintilan, JF Cecillon, Michael Smelie and Rob Cannon. Music Organisation Case Studies. For students studying music organisation in arts management or music business programs. Melbourne, Australia: Australian College of the Arts.

Saintilan, Paul and Rob Cannon. 2013. "The Taste Case. Should Artistic Leaders Drive Decision Making from Their Own Taste?" (Case study 2). In Paul Saintilan, JF Cecillon, Michael Smelie and Rob Cannon. Music Organisation Case Studies. For students studying music organisation in arts management or music business programs. Melbourne, Australia: Australian College of the Arts.

Šaver, Boštjan. 2005. Nazaj v planinski raj. Alpska kultura slovenstva in mitologija Triglava. Ljubljana: Fakulteta za družbene vede.

Sivec Ivan. 1999. Fenomen Ansambla bratov Avsenik. [Master's thesis]. Ljubljana: Oddelek za etnologijo in kulturno antropologijo, Filozofska fakulteta. 
Sivec Ivan. 2010. Brata Avsenik. Evropski glasbeni fenomen iz Begunj na Gorenjskem. Begunje: Galerija Avsenik - Hohner.

Spang Goodrich, Peter and Nancy E. Rossiter. 2010. "The Entrepreneurial Drive of Folk Musicians". Academic and Business Research Institute Conference, Conference Proceedings. Las Vegas. Available at: http://www.aabri.com/LV2010Manuscripts/LV10129.pdf (accessed 13 December 2013).

Strašnik, Simona. 2010. Nastanek in razvoj narodno-zabavne glasbe v kulturnozgodovinskem kontekstu na Slovenskem. [Diploma seminar thesis]. Maribor: Univerza v Mariboru, Filozofska fakulteta, Oddelek za sociologijo.

Torkar, Klemen. 2008. Reprezentacija narodno-zabavne glasbe $v$ medijih $v$ Sloveniji. [Undergraduate thesis]. Ljubljana: Univerza v Ljubljani, Fakulteta za družbene vede.

\section{GLAZBENO PODUZETNIŠTVO I OBITELJSKI POSAO: PRIMJER ANSAMBLA BRAĆE AVSENIK}

Od samih početaka u malom selu Begunje u sjevernom alpskom dijelu Gorenjske u Sloveniji, predanost Ansambla braće Avsenik izvrsnosti i kreativnosti postala je globalni fenomen koji je ovu vrstu glazbe proširio po čitavoj Europi (posebice u njemačkom govornom području) kao i diljem svijeta. Danas obiteljsku tradiciju aktivno pronose Slavkov sin Gregor i unuk Sašo, koji nastavljaju umjetnost obitelji Avsenik te vode obiteljski posao koji je oko nje nastao. U Begunju - koje je i dalje njihovo sjedište - obitelj Avsenik vodi ansambl od sedam glazbenika, restoran, galeriju, muzej, glazbenu izdavačku kuću, glazbenu školu kao i višenamjenski društveni centar. Poslovni model obitelji Avsenik razvijao se od njihovih doista skromnih početaka kada su učili kako se neprestano prilagođavati novim izazovima, do njihovog današnjeg poslovnog modela koji se temelji na izboru onoga što je najbolje, na prilagođavanju glazbenim i zabavnim sadržajima koji su se dokazali kao uspješni, poznavanju glazbenog ukusa masa te korištenju novih tehnologija. Dakako, riječ je i o sretnim okolnostima, odnosno o činjenici da su se našli na pravom mjestu u pravo vrijeme, što je pridonijelo njihovoj slavi. Bliske obiteljske veze, jasna vizija i profesionalnost nagrađeni su velikim uspjehom. S vremenom i sve većim iskustvom, braća Avsenik razvili su mrežu podrške za sve koji su dio njihovog ansambla, posvetili se kontroli kvalitete, razvijali organizacijski duh, te ulagali u poslovne inicijative i ustrajnost, pouzdajući se u pojedinačni i zajednički uspjeh. Nadalje, učili su iz vlastitih pogrešaka, a posebno naivnosti i povjerenja u pogrešne ljude koji su mnogo puta imali koristi od njihove glazbe i nastupa. Treća generacija obitelji Avsenik, Ansambl Saše Avsenika, u glazbenu je industriju ušao sa značajnim kulturnim kapitalom. Njihovo je ime poznato, imaju glazbeno nasljeđe obitelji Avsenik kao i financijsku potporu obitelji.

Ključne riječi: narodna zabavna glazba, obitelj Avsenik, Slovenija, glazbena industrija, antropologija poslovanja, vodstvo, glazbeno poduzetništvo 